\title{
Expression of thyrotropin-releasing hormone receptor in immortalized $\beta$-cell lines and rat pancreas
}

\author{
L-G Luo and N Yano \\ Hallett Center for Diabetes and Endocrinology, Rhode Island Hospital, Brown Medical School, 593 Eddy Street, Providence, Rhode Island 02903, USA \\ (Requests for offprints should be addressed to L-G Luo; Email: Lu-Guang Luo@Brown.edu)
}

\begin{abstract}
Thyrotropin-releasing hormone (TRH), a hypothalamic tripeptide, is expressed in pancreatic islets at peak levels during the late gestation and early neonate period. TRH increases insulin production in cultured $\beta$-cells, suggesting that it might play a role in regulating pancreatic $\beta$-cell function. However, there is limited information on TRH receptor expression in the pancreas. The aim of the present study was to explore the distribution of the TRH receptor in the pancreas and its function in pancreatic $\beta$-cells. TRH receptor type 1 (TRHR1) gene expression was detected by RT-PCR and verified by Northern blotting and immunoblotting in the $\beta$-cell lines, INS-1 and $\beta$ TC- 6 , and the rat pancreatic organ. The absence of TRH receptor type 2 expression in the tissue and cells indicated the tissue specificity of TRH receptor expression in the pancreas. The TRHR1 signals (detected by in situ
\end{abstract}

hybridization) were distributed not only in islets but also in the surrounding areas of the pancreatic ductal and vasal epithelia. The apparent dissociation constant value for the affinity of $\left[{ }^{3} \mathrm{H}\right] 3$-methyl-histidine TRH (MeTRH) is $4 \cdot 19$ in INS-1 and 3.09 $\mathrm{nM}$ in $\beta$ TC-6. In addition, TRH induced epidermal growth factor (EGF) receptor phosphorylation with a half-maximum concentration of approximately $50 \mathrm{nM}$, whereas the high affinity analogue of TRH, MeTRH, was $1 \mathrm{nM}$. This suggested that the affinity of TRH ligands for the TRH receptor influences the activation of EGF receptor phosphorylation in $\beta$ TC- 6 cells. Our observations suggested that the biological role of TRH in pancreatic $\beta$-cells is via the activation of TRHR1. Further research is required to identify the role of TRHR 1 in the pancreas aside from the islets.

Journal of Endocrinology (2004) 181, 401-412

\section{Introduction}

Thyrotropin-releasing hormone (TRH), originally characterized and extensively studied as a hypothalamic tripeptide, plays a key role in the regulation of the thyroid axis (Hajjar et al. 1973, Azizi et al. 1974, Jackson et al. 1974a,b, Martino et al. 1978). In addition to the hypothalamus, TRH has been identified in many systemic organs including the pancreas (Martino et al. 1978, Koivusalco \& Leppaluoto 1979, Morley et al. 1979, Engler et al. 1982, Aratan-Spire et al. 1984, Leduque et al. 1985, Fuse et al. 1990). In the pancreas, TRH expression is at its peak during the neonatal period and gradually declines after birth (Martino et al. 1978, Basmaciogullari et al. 2000). The distribution of TRH in the pancreas has been localized in both the islet $\beta$-cells and other pancreatic cells (Basmaciogullari et al. 2000). TRH promotes insulin release from adult islets (Kulkarni et al. 1995) and TRH gene knockout induces mild hyperglycemia (Yamada et al. 1997), suggesting that the expression of TRH in the pancreas might be involved in the regulation of pancreatic $\beta$-cell function. TRH-induced transactivation of the epidermal growth factor (EGF) receptor in an immortalized $\beta$-cell line (Luo et al. 2002) implies that TRH might influence $\beta$-cell differentiation and development through cross-talk with a growth factor receptor.

Two subtypes of TRH cognate receptors have been identified. TRH receptor type 1 (TRHR1) was originally cloned in 1990 using expression cloning in Xenopus laevis (Straub et al. 1990) and TRH receptor type 2 (TRHR2), which was identified in 1998 by two groups simultaneously (Cao et al. 1998, Itadani et al. 1998). Although TRHR 1 and 2 share no more than $68 \%$ homology of their amino acid sequence, there are no significant differences in binding or in acute stimulation of signaling between the subtypes (O'Dowd et al. 2000, Sun et al. 2003).

The distribution of TRHR 2 in brain tissues is more extensive than that of TRHR1 (Sun et al. 2003) and TRHR2 localization is strictly limited in the central nervous system (CNS). TRHR2 is more rapidly bound to TRH and has a greater level of TRH-induced downregulation than TRHR1 (O'Dowd et al. 2000). All the findings suggest that TRHR2 mediates many of the known functions of TRH that are not transduced by TRHR1 in the CNS (O'Dowd et al. 2000). In contrast to TRHR2, TRHR1 is widely distributed in several peripheral tissues (Leduque et al. 1989, Satoh et al. 1993, 1994, Yamada et al. 2000). The tissue-specific diversity of the 
systematic distribution of TRHR1 and TRHR2 accounts for the various biological roles of TRH in peripheral tissues separate from the CNS and possibly by the autocrine or paracrine cells.

Although TRH expression has been observed in the pancreatic islet, only one report has identified the expression of the TRH receptor in the $\beta$-cell line and islet (Yamada et al. 2000). In the present study, we have identified the distribution of the TRH receptor in the rat pancreas and its expressions in the immortalized $\beta$-cell lines, INS-1 and $\beta$ TC- 6 . The affinity of the expressed TRHR1 was evaluated by binding assay. The biological functions of TRH on insulin production and EGF receptor phosphorylation were determined in the $\beta$-cell lines.

\section{Materials and Methods}

\section{Cell culture}

Unless stated otherwise, media, supplements and all other materials used for cell culture were obtained from Invitrogen (Carlsbad, CA, USA).

Mouse pancreatic $\beta$-cell line, $\beta$ TC- 6 , was provided by the American Type Culture Collection (Manassas, VA, USA). Rat cell line INS-1 was a gift from Dr Claes Wollheim (Centre Médical Universitaire, Geneva, Switzerland). $\beta$ TC-6 cells were grown in Dulbecco's modified Eagle's medium supplemented with 15\% fetal bovine serum (FBS). INS-1 cells were cultured in RPMI1640 with $10 \%$ FBS and $50 \mu \mathrm{M}$ 2-mercaptoethanol to maintain differentiation. Semi-confluent (80-90\%) monolayer cells in $100 \mathrm{~mm}$ polystyrene dishes (Becton Dickinson, Lincoln Park, NJ, USA) and 15-40 cell passages were used for the experiments.

\section{RT-PCR and PCR direct sequencing}

Total RNA was isolated from cells using TRIzol Reagent (Invitrogen). As described previously (Yano et al. 1997), cDNA was generated from $5 \mu \mathrm{g}$ of the total RNA by reverse transcription. cDNA was subject to 30 cycles of PCR using the following primers: TRHR1 sense (rat), 5'-GCC CTC GAG TAC CAG GTG GTC ACC ATC-3'; TRHR1 antisense (rat), 5'-AGT AGT AGT TGC GGG AGA TCT TGT AGC CA-3'; TRHR1 sense (mouse), 5'-GCC CTC GAG TAC CAG GTG GTT ACC ATC-3'; TRHR1 antisense (mouse), 5'-AGT AGT AGT TCC TGG AGA TCT TGT AGC CA-3'; TRHR2 sense (rat), 5'-ATC AAT GTC TCC TCC TTC TCC ATC C-3'; TRHR2 antisense (rat), 5'-GAC AAC GGG CTC TGA AAT AAA ATC C-3'; TRHR2 sense (mouse), 5'-ATC AAT GTC TCC TCC TGC TCC ATC C-3'; TRHR2 antisense (mouse), 5'-GAC AAT GGG CTC TGA AAT AAG ATC C- $3^{\prime}$. Each cycle consisted of $1 \mathrm{~min}$ at $94^{\circ} \mathrm{C}, 2 \mathrm{~min}$ at $65^{\circ} \mathrm{C}$ and $2 \mathrm{~min}$ at $72{ }^{\circ} \mathrm{C}$. The PCR product was run on $2 \%$ agarose gel, stained with ethidium bromide and then photographed. For sequencing analysis, the band from the PCR product was extracted and reconstituted in Tris-EDTA buffer after being run on $1 \%$ agarose gel and directly analyzed by the Taq DNA polymerase cycle sequence method as described previously (Yano et al. 1998). The sense primer that was used for RT-PCR was used as a primer for the sequencing. Each sequencing cycle consisted of $15 \mathrm{~s}$ at $94^{\circ} \mathrm{C}, 45 \mathrm{~s}$ at $64{ }^{\circ} \mathrm{C}$ and $60 \mathrm{~s}$ at $70{ }^{\circ} \mathrm{C}$. After 30 cycles of the reaction, alkaline heat-denatured samples were loaded onto sequencing gel. Analysis was performed using an automated DNA sequencer (model ABI PRISM 377; Perkin-Elmer, Foster City, CA, USA) at the Brown University Automated DNA Sequencing Facility. By manipulating the RT-PCR procedure, it was found that lowering $\mathrm{Mg}^{2+}$ concentrations in the PCR reaction down to $5 \mathrm{mM}$ generated a consistent PCR product. The product generated from this method for sequence analysis also proved consistent for TRHR1.

\section{Northern blotting}

Preparation of TRHR1 probe The University of Iowa (UI) rat EST clone including fragments of the TRHR1 sequence in pT7T3D-Pac vector (UI-R-B00-agm-g-01$0-\mathrm{UI})$ was purchased from Invitrogen. The clone was seeded on an LB agar plate and a single colony that grew on the plate was picked up and its insert was amplified by PCR using universal PCR primers. The sequences of the primers were as follows: T7-95 upper primer, 5'-TTA ATA CGA CTC ACT ATA GGG -3' and T3-94 lower primer, 5'-AAT TAA CCC TCA ATA AAG GG-3'.

The PCR product from the EST clone was purified by running on agarose gel and extraction. The probe was generated by labeling the purified PCR product with dCTP $\left[\alpha_{-}{ }^{32} \mathrm{P}\right]$ (ICN Pharmaceutical, Inc., Bryan, $\mathrm{OH}, \mathrm{USA}$ ) using random primers DNA labeling systems (Invitrogen).

Hybridization Isolated RNA from each sample $(10 \mu \mathrm{g})$ was run on $1 \%$ agarose gel in $1 \times$ MOPS and $2 \cdot 2 \mathrm{M}$ formaldehyde, and then transferred to positively charged nylon membrane (Immobilon- $\mathrm{Ny}^{+}$; Millipore, Billerica, MA, USA). After the transfer, RNA on the membrane was immobilized using an automated u.v. cross-linker (Stratagene, La Jolla, CA, USA) and hybridized with dCTP $\alpha-{ }^{32} \mathrm{P}$-labeled probe in $50 \%$ formamide hybridization buffer for $16 \mathrm{~h}$ at $65^{\circ} \mathrm{C}$ with continuous rotation. After the hybridization, the membranes were washed four times under highly stringent conditions and exposed to BioMax MS high-sensitivity film (Eastman Kodak Co., Rochester, NY, USA).

\section{In situ hybridization}

Fresh frozen rat pancreas was cut into $5 \mu \mathrm{m}$ slices and mounted on glass slides that were immediately fixed in $4 \%$ 
paraformaldehyde in phosphate-buffered saline (PBS) then dehydrated with ethanol. A PCR DIG probe synthesis kit (Roche Diagnostic, Indianapolis, IN, USA) was used to generate a digoxigenin guanosine $5^{\prime}$-tri-phosphate-labeled PCR probe and labeled probe was verified by dot blotting. For prehybridization, the slides were incubated with $50 \%$ formamide and $10 \times$ Denhardt's solution at $42{ }^{\circ} \mathrm{C}$ for $2 \mathrm{~h}$. Hybridization was performed with a denatured TRH receptor digoxigenin-labeled probe at $20 \mathrm{ng}$ in 50\% formamide and $10 \times$ Denhardt's solution containing $50 \mathrm{mg} / \mathrm{ml}$ tRNA and $10 \mathrm{mg} / \mathrm{ml}$ denatured sperm DNA was incubated at $42{ }^{\circ} \mathrm{C}$ for $16 \mathrm{~h}$. After hybridization, the slides were washed with $50 \%$ formamide in $2 \times$ SSC for $20 \mathrm{~min}, 1 \times$ SSC for $15 \mathrm{~min}$ at room temperature and then treated with RNase A (20 $\mu \mathrm{g} / \mathrm{ml}$ in RNase buffer) for $10 \mathrm{~min}$ at $37^{\circ} \mathrm{C}$ and washing with $1 \times$ SSC twice for $5 \mathrm{~min}$ each. The slides were exposed to $200 \mu \mathrm{g} / \mathrm{ml}$ digoxigenin-alkaline phosphatase-fluorescein (Boehringer Mannheim, Indianapolis, IN, USA) in 1\% PBS blocking solution, incubated for $30 \mathrm{~min}$ at $37^{\circ} \mathrm{C}$ and washed twice with PBS solution for $5 \mathrm{~min}$ each time. After hybridization, immunohistochemistry was performed on the same slide. The slide was blocked with 3\% normal goat serum for $20 \mathrm{~min}$ and incubated with mouse anti-insulin monoclonal antibody (CHEMICON, Temecula, CA, USA) for $2 \mathrm{~h}$ at room temperature. After being washed three times, the slide was incubated with anti-mouse biotin conjunction second antibody (1:50) for $20 \mathrm{~min}$, washed five times and Avidin-Texas red (1:100; Vector Laboratories Inc., Burlingame, CA, USA) was added for $10 \mathrm{~min}$ at $37^{\circ} \mathrm{C}$. After washing with PBS with 5\% Tween 20 five times, the slides were covered with Vectashield Dapi in mounting medium (Vector Laboratories, Inc., Burlingame, CA, USA) for nucleus staining and examined under a microscope with filter excitation at $494 \mathrm{~nm}$ and emission at $523 \mathrm{~nm}$. Controls included slides hybridized in the absence of either the digoxigenin-labeled probe or the AP-conjugated antibody. Background labeling was observed when hybridization was conducted with the corresponding sense probes. A slide from a series of sections in the same sample stained with hematoxylin and eosin (HE) was assessed for histological structure (Luo et al. 1995, Luo \& Jackson 1998).

\section{Immunoprecipitation}

Cell lysates were mixed with agarose-conjugated antibody and incubated overnight at $4{ }^{\circ} \mathrm{C}$ with gentle rotation. The lysate-antibody mixture was washed three times with RIPA buffer (20 mM Tris-HCl, pH 7·4, 0-1\% SDS, $1 \%$ Triton X-100 and 1\% sodium deoxycholate). After removing the washing buffer, the sediment was resuspended with $50 \mathrm{ml} 2 \times$ SDS protein sample buffer then vortexed vigorously. After being left at room temperature for $40 \mathrm{~min}$, the mixtures were centrifuged at $1500 \mathrm{~g}$ for $5 \mathrm{~min}$ and all the supernatants were processed for immunoblotting as described in the following section on Western blotting.

\section{Western blotting}

Cells or tissue homogenates were lysed in lysis buffer containing phosphatase inhibitors $(50 \mathrm{mM}$ Tris $-\mathrm{HCl}$, $\mathrm{pH} 7 \cdot 5,0 \cdot 2 \%$ Sigma phosphatase inhibitor cocktail II (Sigma) and 0.1\% Nonidet P-40) and shaken on ice for $2 \mathrm{~h}$. After being centrifuged at $10000 \mathrm{~g}$ for $30 \mathrm{~min}$ at $4{ }^{\circ} \mathrm{C}$, the supernatant was collected and the protein content of all samples was determined with a spectrophotometric protein assay kit (Pierce, Rockford, IL, USA). An identical amount of protein (usually $50 \mu \mathrm{g} /$ lane) was subjected to polyacrylamide mini gels. After transfer, nitrocellulose membranes were blocked in a solution of 5\% milk and $0.5 \%$ Tween 20 in Tris-buffered saline for $2 \mathrm{~h}$ and incubated with specific antibodies overnight at $4{ }^{\circ} \mathrm{C}$ followed by HRP-conjugated second antibody. After washing, protein bands were identified by enhanced chemiluminescence (Super Signal; Pierce) and BioMax MS high sensitive X-ray film (Eastman Kodak Co.) (Luo et al. 1999).

\section{Binding assay}

The TRH-binding assay was performed in 12-well plates $\left(10^{6}\right.$ cells/well $)$ after 2 days of cell culture. $\left[{ }^{3} \mathrm{H}\right] \mathrm{L}-$ histidyl4- ${ }^{3} \mathrm{H}(\mathrm{N})$,L-prolyl-3,4- ${ }^{3} \mathrm{H}(\mathrm{N})$ (MeTRH; NET705; $72 \mathrm{Ci} /$ mmol; Perkin-Elmer) was utilized for binding study. Before binding, $\beta$-cells were washed twice with PBS. The binding was carried out in a $0.5 \mathrm{ml}$ volume of medium (Hank's balanced salt solution and $10 \mathrm{mM}$ HEPES, $\mathrm{pH} 7 \cdot 4$ ) containing various concentrations of MeTRH (Sigma) a high affinity analogue of TRH, from 0.001 to $50 \mathrm{nM}$ with a total of 12 concentration points at $4{ }^{\circ} \mathrm{C}$ for $6 \mathrm{~h}$. To evaluate non-specific binding, 500- to 1000-fold excess unlabeled MeTRH was added to parallel wells in addition to MeTRH. After the binding reaction at room temperature for $1 \mathrm{~h}$, cells were washed twice with cold assay medium and dissolved in $0.4 \mathrm{M}$ $\mathrm{NaOH}$, and the radioactivity was calculated by subtracting the non-specific binding from MeTRH binding in the absence of unlabeled MeTRH. The saturation plot was analyzed by Sigma Plot program (SPSS Inc., Chicago, IL, USA).

\section{Insulin ELISA}

INS- 1 and $\beta$-TC6 cells at $5 \times 10^{5}$ cells/well were incubated in 24-well culture plates. After incubation with serum-free medium overnight, the cells were incubated with or without $200 \mathrm{nM}$ TRH for $24 \mathrm{~h}$ in insulin-free medium. After the incubation, culture media were collected and cell contents were extracted from scraped-off 
A

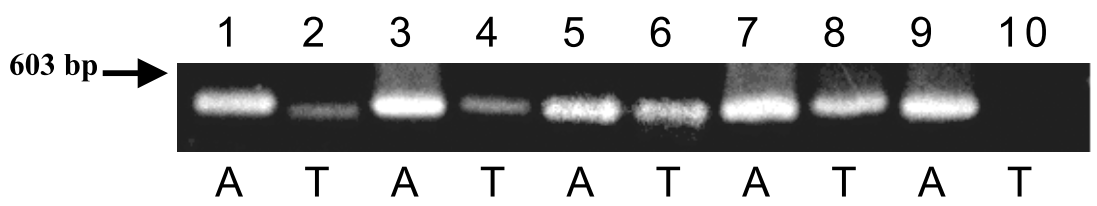

B

\begin{tabular}{|c|c|c|c|}
\hline Query: & 1 & $\begin{array}{l}\text { gccctcgagtaccaggtggtcaccatcttacttgtggnggttatctgtggactgggcatt } \\
||||||||||||||||||||||||||||||||||||||||||||||||||||||||||||||\end{array}$ & 60 \\
\hline Sbjet: & 328 & gccctcgagtaccaggtggtcaccatcttacttgtggtggttatctgtggactgggcatt & 387 \\
\hline Query: & 61 & $\begin{array}{l}\text { gtgggcaacatcatggtagtcctggtggtcatgagaacgaagcacatgagaaccgctaca } \\
||||||||||||||||||||||||||||||||||||||||||||||||||||||||||||||||||||\end{array}$ & 120 \\
\hline Sbjet: & 388 & gtgggcaacatcatggtagtcctggtggtcatgagaacgaagcacatgagaaccgctaca & 447 \\
\hline Query: & 121 & $\begin{array}{l}\text { aactgctacctggtgagtctggctgtggcggatctcatggtcetggtggctgcaggcctc } \\
||||||||||||||||||||||||||||||||||||||||||||||||||||||||||||||||||||\end{array}$ & 180 \\
\hline Sbjet: & 448 & aactgctacctggtgagtctggctgtggcggatctcatggtcctggtggctgcaggcctc & 507 \\
\hline Query: & 181 & $\begin{array}{l}\text { cccaacatcaccgacagcatctatggttcctgggtctatggctatgttggctgcctctgc } \\
|||||||||||||||||||||||||||||||||||||||||||||||||||||||||||||||||| \mid\end{array}$ & 240 \\
\hline Sbjet: & 508 & cccaacatcaccgacagcatctatggttcctgggtctatggctatgttggctgcctctgc & 567 \\
\hline Query: & 241 & $\begin{array}{l}\text { atcacgtatctccagtacttaggaattaacgcatctcatgctcaataacagccttecc } \\
|||||||||||||||||||||||||||||||||||||||||||||||||||||||||||||||||| \mid\end{array}$ & 300 \\
\hline Sbjet: & 568 & atcacgtatctccagtacttaggaattaacgcatcttcatgctcaataacagcctttacc & 627 \\
\hline Query: & 301 & $\begin{array}{l}\text { attgagaggtacatagcaatctgccaccccatcaaagcccagtttctgtgcacatttecc } \\
||||||||||||||||||||||||||||||||||||||||||||||||||||||||||||||||||||\end{array}$ & 360 \\
\hline Sbjet: & 628 & attgagaggtacatagcaatctgccaccccatcaaagcccagtttctgtgcacattttcc & 687 \\
\hline Query: & 361 & $\begin{array}{l}\text { agagccnnnnnntcattatcttgtctgggcettacatccatttactgtatgctgtgg } \\
||||||||||||||||||||||||||||||||||||||||||||||||||||||||||\end{array}$ & 420 \\
\hline Sbjet: & 688 & agagccaaaaaatcattatctttgtctgggccttacatccatttactgtatgctgtgg & 747 \\
\hline Query: & 421 & 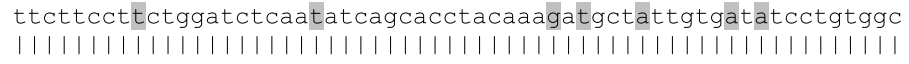 & 480 \\
\hline Sbjet: & 748 & ttcttccttctggatctcaatatcagcacctacaaagatgctattgtgatatcctgtggc & 807 \\
\hline Query: & 481 & $\begin{array}{l}\text { tacaagatctcccgcaactactact } 505 \\
|||||||||||||||||||||||| \mid\end{array}$ & \\
\hline Sbjet: & 808 & tacaagatctcccgcaactactact 832 & \\
\hline
\end{tabular}

Figure 1 TRHR1 gene expression in $\beta$ TC-6, INS-1 and pancreas. (A) cDNA was prepared from cell lines/pancreas and RT-PCR was performed using TRHR1 gene-specific primer pairs. The image represents the result from a 30 -cycle amplification of TRHR1 (T) along with the internal control, $\beta$-actin (A). Lanes 1 and 2, $\beta$ TC-6 cells; lanes 3 and 4, INS-1 cells; lanes 5 and 6, pancreas; lanes 7 and 8, pituitary (positive control); lanes 9 and 10, liver (negative control). (B) A result of PCR direct sequences from INS-1 cells sample (Query) showed 98\% (497/505) homology to mouse TRHR1 gene in NCBI BLASTn Entrez. Sbjct represents partial sequence of TRHR1 (GenBank NM013696). The sense primer sequence is shown as bold underlined characters. Shaded nucleotides indicate positions different from mouse ( $\beta$ TC-6) sequencing results. 
cells with 5\% trichloracetic acid (TCA) then neutralized with $4 \mathrm{M}$ Tris buffer. Six controls and six TRH-treated cells were tested separately in each group. Insulin concentrations were measured using an ultrasensitive rat insulin ELISA kit (Crystal Chem Inc., Downer Grove, IL, USA) according to the manufacturer's instructions. Briefly, insulin standards and appropriately diluted (1:50-1:500) cell extracts and media were added to insulin antibodycoated 96-well microplates and incubated for $2 \mathrm{~h}$ at $4{ }^{\circ} \mathrm{C}$. After washing five times, anti-rat insulin enzyme conjugate was added to the well and incubated for $30 \mathrm{~min}$ at room temperature. After washing seven times, enzyme substrate solution was added, then incubated for up to $45 \mathrm{~min}$ at room temperature in the dark. The reaction was stopped by adding $1 \mathrm{M}$ sulfuric acid. Absorbance at $450 \mathrm{~nm}$ was read with a $\mu$ Quant microplate reader (Bio-Tek Instruments, Inc., Winooski, VT, USA) and concentrations were calculated by KC Junior microplate reader software (Bio-Tek Instruments, Inc.).

\section{Image analysis}

Data are shown as means \pm S.D. Densitometric analysis of the blotting image was carried out using Scion Image for Windows (Scion Corp., Frederick, MD, USA). All the graphs from the image data and statistical evaluation (Student's $t$-test) were performed using MS Excel (Microsoft, Redmond, WA, USA) and Sigma Plot software.

\section{Results}

Expression of TRHR1 $m R N A$ in $\beta$-cell lines and rat pancreas

The single distinct band (503 bp) of TRHR 1 mRNA in INS-1, $\beta$-TC6 and rat pancreas was detected by RTPCR (Fig. 1A). Direct DNA sequencing from the PCR product completely matched a TRHR 1 sequence from the GenBank database (Fig. 1B). There were no significant amplifications of TRHR 2 mRNA in the cells and pancreas, although an apparent amplification was detected in the hypothalamus (data not shown). Northern blotting further confirmed a distinct signal of TRHR1 in rat pancreas, INS-1 and $\beta$ TC-6 cells (Fig. 2). With double labeling of non-isotopic in situ hybridization and insulin immunohistochemistry performed in rat pancreatic slides and HE histological staining for pancreatic structure, the distribution of signals for TRHR 1 expression were found to be localized within insulin-stained cells in islets, ductal and vasal epithelia in the pancreas; indicating that the TRH receptor is expressed in both $\beta$-cells in islets and the areas outside of islets (Fig. 3).

\section{Protein expression of TRHR-1 in pancreas}

The presence of TRHR 1 in $\beta$-cell lines as well as in the pancreas was confirmed by receptor protein level.
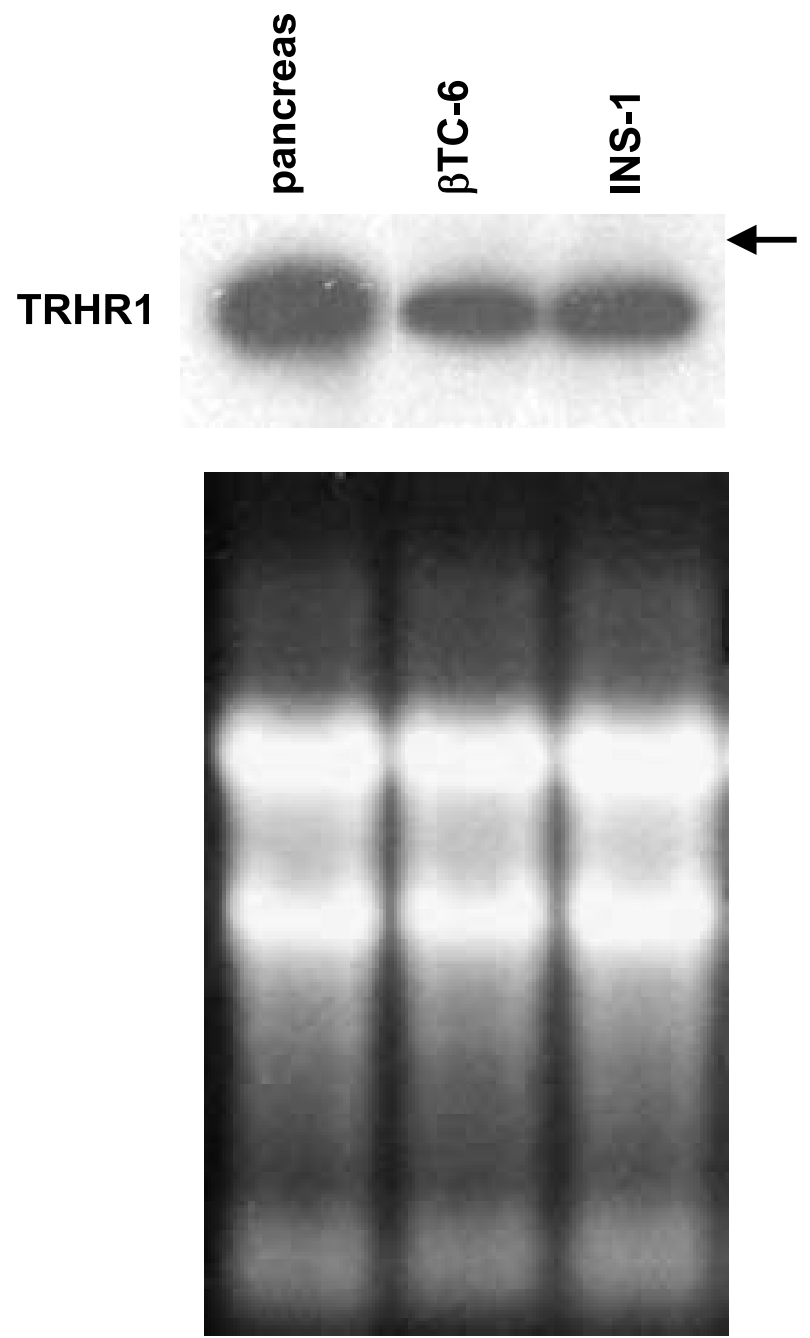

Figure 2 Northern blotting of TRHR 1 in $\beta$ TC-6, INS- 1 and pancreas. Northern blot analysis of TRHR1 mRNA in rat pancreas, $\beta$ TC- 6 and INS- 1 cells. The arrow indicates the position of $28 \mathrm{~S}$ ribosomal RNA. The lower panel shows the ethidium bromide stain of the gel before transferring.

Immunoblotting with TRHR1-specific rabbit polyclonal antibody (Santa Cruz Biotechnology, Inc., Santa Cruz, CA, USA) was applied to detect TRHR 1 protein with a positive control, the pituitary. Figure 4 indicates that the TRHR1 protein was expressed in both $\beta$-cell lines and the pancreas. A stronger expression at the expected size (approximately $40 \mathrm{kDa}$ ) in the pituitary served as a positive control.

\section{Affinity of TRH receptor in INS-1 and $\beta$ TC- 6 cells}

Further functional tests were performed by the binding affinity of TRHR1 with a receptor radiolabeled-binding assay in INS-1 and $\beta$ TC- 6 cells. As shown in Fig. 5, the 


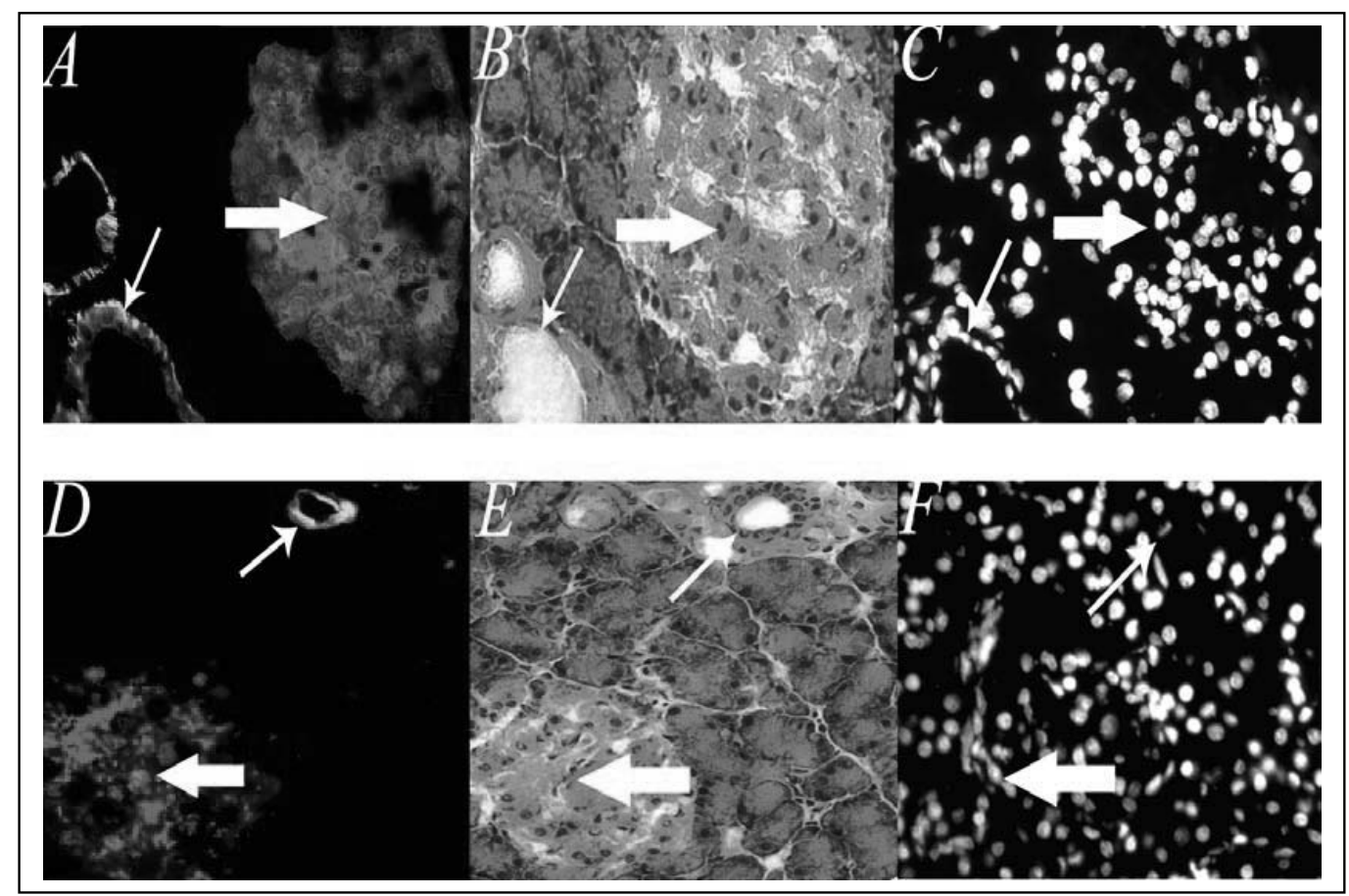

Figure 3 In situ hybridization of TRHR1 in the rat pancreas. $(A)$ and $(D)$ Dual fluorescent image of rat pancreas. Red indicates insulin immunofluorescence; green indicates TRHR1 in situ hybridization; $(B)$ and $(E)$ HE staining for tissue morphology, arrow indicates nuclei; $(C)$ and $(F)$ DAPI for nuclei staining. The large white arrows indicate the yellow color, a mixture of green and red represents co-localization of insulin and TRHR1 in islet and the small white arrows indicate the positive staining of TRHR1 in $(A)$ and $(B)$ epithelial and $(D)$ and $(E)$ ductal cells.

affinity of TRHR1 to $\left[{ }^{3} \mathrm{H}\right] \mathrm{MeTRH}$ was enhanced with increasing concentrations of $\left[{ }^{3} \mathrm{H}\right] \mathrm{MeTRH}$ and was saturable with MeTRH concentrations at $10 \mathrm{nM}$. Scatchard plot analysis revealed that the apparent dissociation constant $\left(K_{\mathrm{d}}\right)$ values for MeTRH in INS-1 and $\beta$ TC-6 were 4.19 and $3.09 \mathrm{nM}$ respectively. The experiment was repeated three times and Sigma Plot software was used as described in Materials and Methods.

Increase in insulin contents and secretion in $\beta$-cell lines with TRH treatment

Insulin levels in cell extracts from $\beta$-TC6 and INS- 1 were measured to evaluate the effects of $\mathrm{TRH}$ on insulin
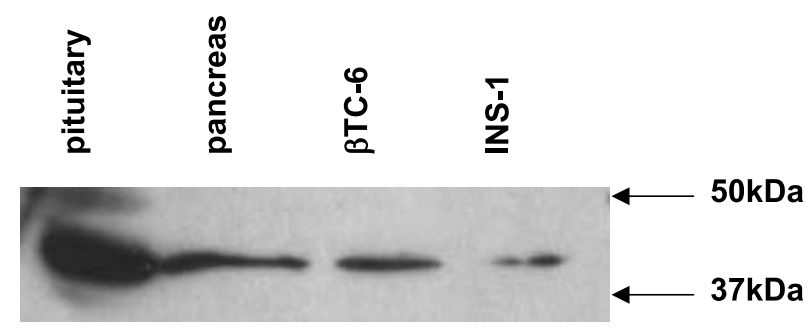

Figure 4 Western blotting of TRHR1 protein. Cell lysates and pancreas homogenate were run on $10 \%$ polyacrylamide gel along with a positive control, the pituitary, and immunoblotted with TRHR1-specific rabbit polyclonal antibody. production and secretion. TRH significantly enhanced insulin production in cell extracts (Fig. 6A: $\beta$ TC-6 (means \pm S.D.) $2931 \cdot 8 \pm 903.5$ vs control $1122 \cdot 7 \pm$ $353.9 \mathrm{ng} / \mathrm{mg}$ protein normalized with protein concentrations in the extracts, $P<0 \cdot 01$ and INS-1: $7573 \cdot 2 \pm$ $2265 \cdot 1$ vs control $2656 \cdot 1 \pm 579 \cdot 8, P<0 \cdot 01$. Fig. 6B: $\beta$ TC-6 (means \pm S.D.) $73 \cdot 0 \pm 8 \cdot 0$ vs control $41 \cdot 7 \pm$ $7 \cdot 8 \mathrm{ng} / \mathrm{ml}, P<0 \cdot 01$ and INS-1: $206 \cdot 9 \pm 41 \cdot 8$ vs control $88 \cdot 3 \pm 9 \cdot 0, P<0 \cdot 01)$.

Activation of EGF receptor phosphorylation by TRH and $\mathrm{MeTRH}$

For further testing of the biological function of TRH in pancreatic $\beta$-cells, EGF receptor phosphorylation in response to TRH was detected by Western blotting (Luo et al. 2002). MeTRH, a high affinity TRH analogue to the TRH receptor, is about tenfold the binding ability of native TRH. The activity of TRH and its analogue on EGF receptor phosphorylation in $\beta \mathrm{TC}-6$ cells was examined with various concentrations of TRH (from 50 to $500 \mathrm{nM}$ ) and MeTRH (from $0 \cdot 1$ to $50 \mathrm{nM}$ ). The cell lysates were immunoprecipitated with agarose-conjugated phosphorylated tyrosine specific antibody (PY20; Santa Cruz Biotechnology, Inc.) and immunoblotted with anti-EGF receptor antibody (SC1005; Santa Cruz 

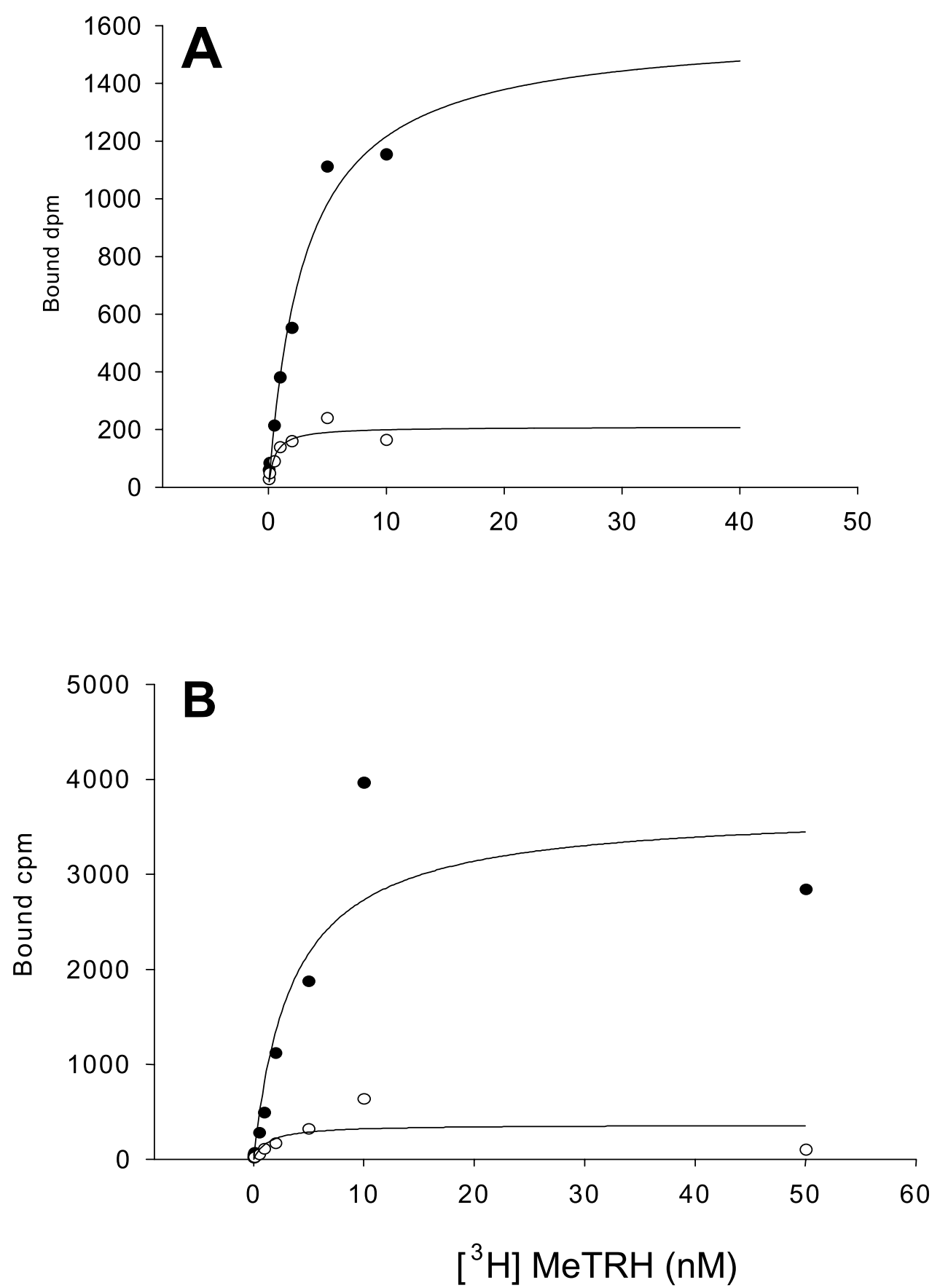

Figure 5 TRH receptor binding in (A) $\beta$ TC- 6 and (B) INS-1 cells. TRH receptor binding was measured by incubation of various concentrations of $\left[{ }^{3} \mathrm{H}\right] \mathrm{MeTRH}$ (fmol/dish $(-)$ ) with $\beta$ TC- 6 and INS- 1 cells and with 1000-fold excess cold MeTRH for non-specific binding $(\mathrm{O})$ for $6 \mathrm{~h}$ at $4{ }^{\circ} \mathrm{C}$. The plot shows one-site saturation binding with $\left.{ }^{3} \mathrm{H}\right] \mathrm{MeTRH}$ and cold MeTRH (non-specific binding). The results indicate that $\beta$ TC- 6 and INS- 1 cells have TRH receptor binding with a $K_{d}$ of (A) 3.09 and (B) $4 \cdot 19 \mathrm{nM}$.

Biotechnology, Inc.). Both TRH and MeTRH activated EGF receptor phosphorylation in a dose-response manner and MeTRH stimulated EGF receptor phosphorylation more than native TRH activation, which indicated TRH cross-talk with the EGF receptor through a TRHR1 mechanism as shown in Figs 7 and 8. Left shift of the MeTRH dose-response curve vs the TRH curve indicated characteristic binding to the TRH receptor. 

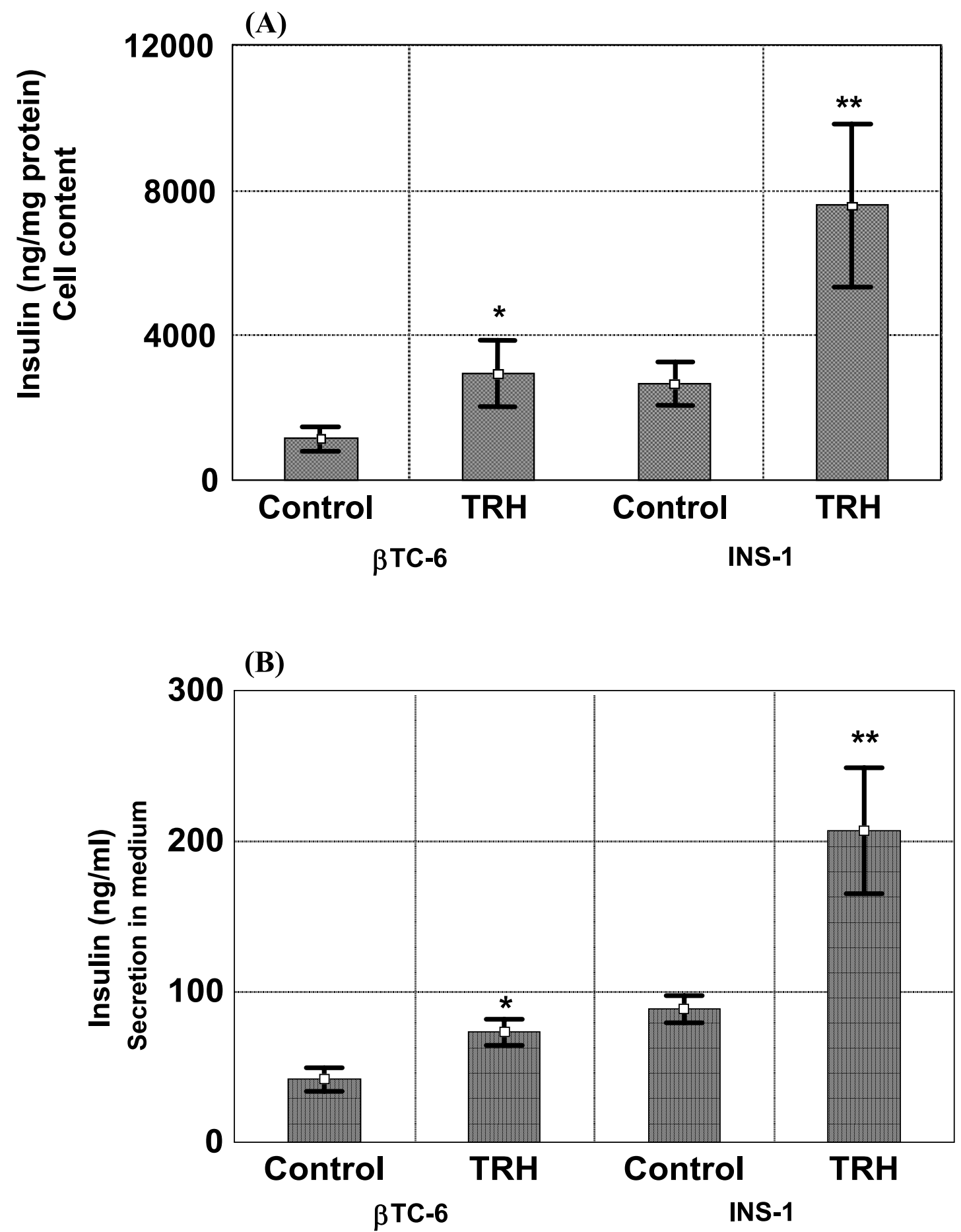

Figure 6 Insulin ELISA for $\beta$ TC-6 and INS- 1 cell extracts and medium. Cells were cultured for $24 \mathrm{~h}$ with or without TRH ( $n=6$ in each group). Culture medium was collected and harvested and cells were extracted by $5 \%$ TCA. Insulin contents and secretion were measured by ELISA. Insulin contents in cells were normalized with protein concentration $(\mathrm{mg} / \mathrm{ml})$ of the extracts. TRH-treated cells contained higher amount of insulin than controls in (A) cell extracts and (B) culture medium. ${ }^{*} P<0 \cdot 01$ vs control $(\beta T C-6),{ }^{*} P<0 \cdot 01$ vs control (INS- 1$)$. 


\section{MeTRH}
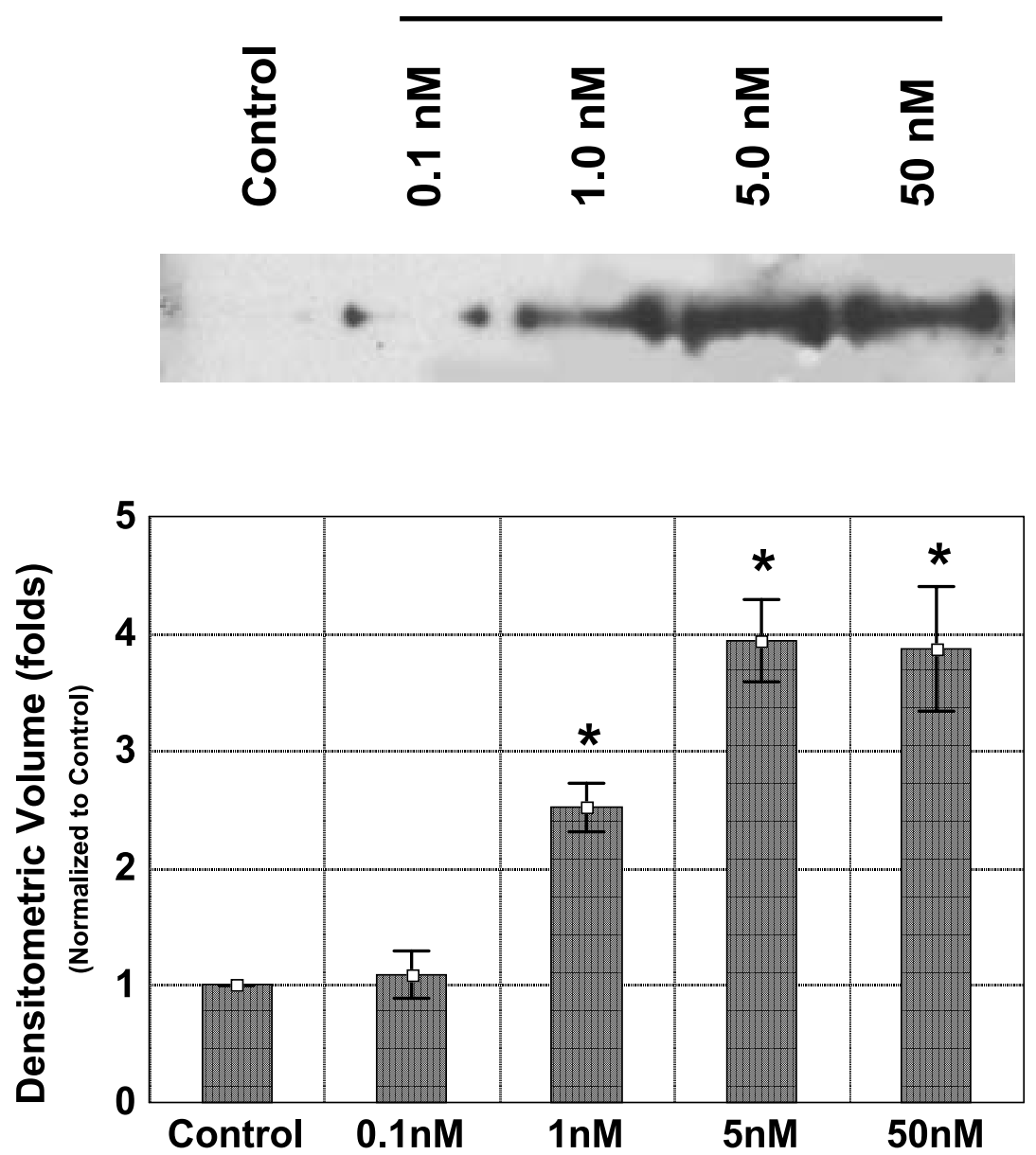

Figure 7 Dose-response effects of MeTRH on EGF receptor phosphorylation. $\beta$ TC- 6 cells were incubated with 0.1-50 nM MeTRH, and EGF receptor tyrosine phosphorylation was assessed by sequential immunoprecipitation and immunoblotting. MeTRH stimulated tyrosine phosphorylation of EGF receptors with a dose-response curve characteristic of its binding to the TRH receptor $(0 \cdot 1-50 \mathrm{nM})$. The graph represents densitometric analysis of immunoblotting signals (means \pm S.D.) from three separate experiments. ${ }^{*} P<0 \cdot 05$ vs controls.

\section{Discussion}

The pancreatic organ or cell lines are known to show similarity in the developmental process or gene expression patterns, which are found in neurons and possess variable neuronal derivative peptides and hormones (Wolff et al. 1996, Emanuel et al. 2000, Lumelsky et al. 2001). The expressions of TRH (Koivusalco \& Leppaluoto 1979) and its biological effects on pancreatic $\beta$-cells and pancreas have been reported (Kulkarni et al. 1979, Glasbrenner et al. 1990, Yamada et al. 2000). In the present study, TRH enhanced insulin production in cultured $\beta$-cell lines, which indicated that TRH directly affects pancreatic $\beta$-cells. However, in spite of the suggestive findings, the biological role and mechanisms of endogenous
TRH directly upon the pancreas have not been fully elucidated.

There are two types of TRH receptors (TRHR1 and TRHR2) which have been identified previously (Straub et al. 1990, Cao et al. 1998, Itadani et al. 1998). More recently, a third subtype of the receptor (TRHR3) has been cloned from Xenopus laevis (Bidaud et al. 2002). TRHR 3 is distributed similarly to TRHR 2 in the CNS. However, due to an extremely low affinity of the new molecule to TRH in comparison with TRHR 1 and 2, the novel receptor has not been determined to be a true cognate ligand of TRH (Lu et al. 2003). TRHR1 is widely distributed in the CNS and extends to several peripheral organs (Calzá et al. 1992, Satoh et al. 1993, 1994, Zabavnik et al. 1993, Wolff et al. 1996) compared with TRHR2. 

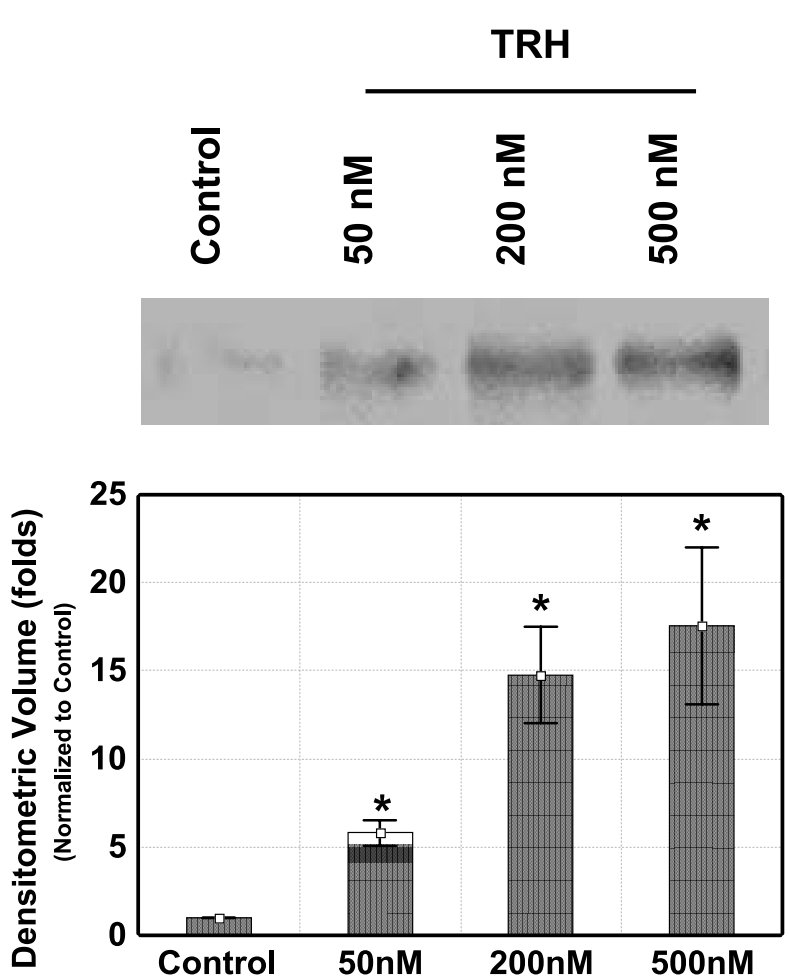

Figure 8 Dose-response effects of TRH on EGF receptor phosphorylation. $\beta$ TC- 6 cells were incubated with $50-500 \mathrm{nM}$ $\mathrm{TRH}$, and EGF receptor tyrosine phosphorylation was assessed by sequential immunoprecipitation and immunoblotting. TRH stimulated tyrosine phosphorylation of EGF receptors with a dose-response curve characteristic of its binding to the TRH receptor (50-500 $\mathrm{nM}$ ). The graph represents densitometric analysis of immunoblotting signals (means \pm S.D.) from three repeated experiments. ${ }^{*} P<0 \cdot 05$ vs controls.

Therefore, the putative biological function of TRH in peripheral organs, including the effects of TRH on pancreatic cells, is probably mediated by TRHR 1 .

In the present study, we have demonstrated the transcription and translation of TRHR 1 in an immortalized $\beta$-cell line and rat pancreas. It is the first report to find strong TRH receptor expression not only in the islet but also in the ductal and epithelial cells surrounding the endocrine cells in the pancreas, which could explain the findings that mRNA expression from the entire pancreas in Northern blotting is stronger than that in $\beta$-cell lines (Fig. 2). The physiological significance of the wide distribution of TRHR1 in the pancreas needs to be further explored. The affinity of the expressed TRHR 1 has been verified by receptor binding analysis and the results revealed that the TRH receptor in an immortalized $\beta$-cell line possesses modest affinity $\left(K_{\mathrm{d}}\right.$ values for INS-1 and $\beta$ TC-6 were 4.19 and 3.09 nM respectively). The affinities were generated from 12 different concentrations with a maximum of $50 \mathrm{nM}\left[{ }^{3} \mathrm{H}\right] \mathrm{MeTRH}$, which was fivefold higher than the maximum binding concentration $(10 \mathrm{nM})$.
The affinity value calculated from these ranges of concentrations was consistent with other studies (Yamada et al. 2000). TRH increased the $\beta$-cell insulin production and secretion during the $24 \mathrm{~h}$ of incubation, which indicated that TRH and its receptors play an important role in the prolonged regulation of $\beta$-cell function. The previous findings showed that TRH is a candidate in the activation of the phosphorylation of EGF receptor in $\beta$-cells through its cognate receptor and Src kinase-related signal transduction pathway (Luo et al. 2002). This finding prompted us to test whether different affinity analogues of TRH may produce various responses from the EGF receptor. TRH and its analogue, MeTRH, activated phosphorylation of EGF receptor in a dose-response fashion in $\beta$ TC- 6 cells and MeTRH was more potent in phosphorylating the EGF receptor than native TRH. That the biological effect of TRH could be mediated through TRHR 1 and that the receptors on $\beta \mathrm{TC}-6$ cells maintain intact functions indirectly support this. The EGF receptor, in response to MeTRH, had a more than tenfold potent affinity than that of native TRH, which might imply that there are amplificatory pathways between TRH receptor and EGF receptor. Once the higher affinity of MeTRH activates the TRH receptor, the signal might be amplified by multiple signal transduction pathways (Luo et al. 2003) to the end EGF receptor activation.

Since TRH does not directly bind to EGF receptor (Luo et al. 2003), the signal transduction amplificatory effect might explain why EGF receptor transactivation has a relevant action of $G$ protein-coupled receptors linked to Ras/MAP kinase activation (Daub et al. 1996) and protein synthesis (Voisin et al. 2002). Although the specific effects of EGF on insulin synthesis have not been identified, TRH activation of EGF receptor phosphorylation influencing the relative pathways cannot be excluded.

The demonstration of TRH receptor expression and function in pancreatic tissue is as important as elucidating the mechanism of TRH function in the CNS. The presence of both the tripeptide and its receptor in the pancreas suggests that TRH has a specific biological role in these tissues and effects do not occur by a non-specific receptor mechanism.

In conclusion, we have verified the expression of TRHR1 in pancreatic $\beta$-cell lines and rat pancreatic tissue. The expression of TRH and its receptor in pancreatic tissue suggests that TRH might play a biological role in pancreatic cells in an autocrine or paracrine fashion. Further studies are required in order to elucidate the physiological significance of TRHR1 in the various cell types found in the pancreas and the role of TRH in pancreatic development.

\section{Acknowledgements}

The authors are grateful to Professors Robert J Smith for his helpful discussion, Marvin C Gershengorn (NIDDK) 
for his valuable suggestions and John Z Q Luo for assistance in editing the paper and clarifying the images. This work was presented at the 63rd American Diabetes Association Annual Meeting in New Orleans, LA, USA on 13-17 June 2003.

\section{Funding}

This work was funded in part by Dr Luo's developmental and restricted research funds from Lifespan and the Hallett Diabetes Foundation fund.

\section{References}

Aratan-Spire S, Wolf B \& Czernichow P 1984 Developmental pattern of TRH-degrading activity and TRH content in rat pancreas. Acta Endocrinologica 106 102-108.

Azizi F, Vagenakis AG, Bollinger J, Reichlin S, Bush JE \& Braverman LE 1974 The effect of a single large dose of thyrotropin-releasing hormone on various aspects of thyroid function in the rat. Endocrinology 95 1767-1770.

Basmaciogullari A, Cras-Meneur C, Czernichow P \& Scharfmann R 2000 Pancreatic pattern of expression of thyrotropin-releasing hormone during rat embryonic development. Journal of Endocrinology 166 481-488.

Bidaud I, Lory P, Nicolas P, Bulant M, \& Ladram A 2002 Characterization and functional expression of cDNAs encoding thyrotropin-releasing hormone receptor from Xenopus laevis. Identification of a novel subtype of thyrotropin-releasing hormone receptor. European Journal of Biochemistry 269 4566-4576.

Calzá L, Giardino L, Ceccatelli S, Zanni M, Elde R \& Hökfelt T 1992 Distribution of thyrotropin-releasing hormone receptor messenger RNA in the rat brain: an in situ hybridization study. Neuroscience 51 891-909.

Cao J, O’Donnell D, Vu H, Payza K, Pou C, Godbout C, Jakob A, Pelletier M, Lembo P, Ahmad S \& Walker P 1998 Cloning and characterization of a cDNA encoding a novel subtype of rat thyrotropin-releasing hormone receptor. Journal of Biological Chemistry 273 32281-32287.

Daub H, Weiss FU, Wallasch C \& Ullrich A 1996 Role of transactivation of the EGF receptor in signaling by G-protein-coupled receptors. Nature 379 557-560.

Emanuel RL, Torday JS, Asokananthan N \& Sunday ME 2000 Direct effects of corticotropin-releasing hormone and thyrotropin-releasing hormone on fetal lung explants. Peptides 21 1819-1829.

Engler D, Chad D \& Jackson IM 1982 Thyrotropin-releasing hormone in the pancreas and brain of the rat is regulated by central noradrenergic and dopaminergic pathways. Journal of Clinical Investigation 69 1310-1320.

Fuse Y, Polk DH, Lam RW \& Fisher DA 1990 Distribution of thyrotropin-releasing hormone (TRH) and precursor peptide (TRH-Gly) in adult rat tissues. Endocrinology 127 2501-2505.

Glasbrenner B, Malfertheiner P, Duntas L, Buchler M, Bereiter T \& Ditschuneit H 1990 Effects of TRH on pancreatic growth and secretion in rats. Pancreas 5 37-41.

Hajjar RA, Anderson MS \& Samaan NA 1973 Thyrotropin-releasing hormone as a pituitary-function indicator. A comparison with other tests. Archives of Internal Medicine 132 836-839.

Itadani H, Nakamura T, Itoh J, Iwaasa H, Kanatani A, Borkowski J, Ihara M \& Ohta M 1998 Cloning and characterization of a new subtype of thyrotropin-releasing hormone receptors. Biochemical and Biophysical Research Communications 250 68-71.
Jackson IM \& Reichlin S 1974a Thyrotropin releasing hormone (TRH): distribution in the brain, blood and urine of the rat. Life Sciences 14 2259-2266.

Jackson IM \& Reichlin S $1974 b$ Thyrotropin-releasing hormone (TRH): distribution in hypothalamic and extrahypothalamic brain tissues of mammalian and submammalian chordates. Endocrinology 95 854-862.

Koivusalo F \& Leppaluoto J 1979 High TRF immunoreactivity in purified pancreatic extracts of fetal and newborn rats. Life Sciences 24 1655-1658.

Kulkarni RN, Wang ZL, Akinsanya KO, Bennet WM, Wang RM, Smith DM, Ghatei MA, Byfield PG \& Bloom SR 1995 Pyroglutamyl-phenylalanyl-proline amide attenuates thyrotropin-releasing hormone-stimulated insulin secretion in perifused rat islets and insulin-secreting clonal beta-cell lines. Endocrinology 136 5155-5164.

Leduque P, Wolf B, Aratan-Spire S, Dubois PM \& Czernichow P 1985 Immunocytochemical location of thyrotropin-releasing hormone $(\mathrm{TRH})$ in the $\beta$-cells of adult hypothyroid rat pancreas. Regulatory Peptides 10 281-292.

Leduque P, Bulant M, Dubois PM, Nicolas P \& Vaudry H 1989 Processing of thyrotropin-releasing hormone prohormone (pro-TRH) in the adult rat pancreas: identification and localization of pro-TRH-related peptides in $\beta$-cells of pancreatic islets. Endocrinology 125 1492-1497.

Lu X, Bidaud I, Ladram A \& Gershengorn MC 2003 Pharmacological studies of thyrotropin-releasing hormone (TRH) receptors from Xenopus laevis: is xTRHR3 a TRH receptor? Endocrinology 144 1842-1846.

Lumelsky N, Blondel O, Laeng P, Velasco I, Ravin R \& McKay R 2001 Differentiation of embryonic stem cells to insulin-secreting structures similar to pancreatic islets. Science 292 1389-1394.

Luo LG \& Jackson IMD 1995 Thyrotropin-releasing hormone and c-fos/c-jun genes are colocalized in rat anterior pituitary cells: stimulation of transcription by glucocorticoids. Endocrinology 136 2705-2710.

Luo LG \& Jackson IM 1998 Glucocorticoids stimulate TRH and c-fos/c-jun gene co-expression in cultured hypothalamic neurons. Brain Research 791 56-62.

Luo LG, Wang S, Su E \& Jackson I.M 1999 Evidence from studies with N-ethyl-maleimide and 12-O-tetradecanoylphorbol-13-acetate that AP-1 and CREB are involved in the glucocorticoid activation of TRH gene expression in hypothalamic cultures. Brain Research 841 189-192.

Luo LG, Yano N, Zhu YH \& Smith RJ 2002 Activation of EGF receptors in pancreatic beta cells by thyrotropin releasing hormone $(\mathrm{TRH})$ : cross-talk between neuropeptide and growth factor receptors. Diabetes $\mathbf{5 1}$ S1629.

Luo L, Smith R \& Yano N 2003 Mechanisms of epidermal growth factor (EGF) receptor activation by thyrotropin releasing hormone (TRH) in cultured pancreatic b cells. Diabetes 52 A382 (Abstract).

Martino E, Lernmark A, Seo H, Steiner DF \& Refetoff S 1978 High concentration of thyrotropin-releasing hormone in pancreatic islets. PNAS 75 4265-4267.

Morley JE 1979 Extrahypothalamic thyrotropin releasing hormone (TRH) - its distribution and its functions. Life Sciences $\mathbf{2 5}$ $1539-1550$.

O’Dowd BF, Lee DK, Huang W, Nguyen T, Cheng R, Liu Y, Wang B, Gershengorn MC \& George SR 2000 TRH-R2 exhibits similar binding and acute signaling but distinct regulation and anatomic distribution compared with TRH-R1. Molecular Endocrinology 14 183-193.

Satoh T, Feng P, Kim UJ \& Wilber JF 1993 Identification of thyrotropin-releasing hormone receptor messenger RNA in the rat central nervous system and eye. Brain Research. Molecular Brain Research 19 175-178. 
Satoh T, Feng P, Kim UJ \& Wilber JF 1994 Identification of thyrotropin-releasing hormone receptor in the rat testis. Neuropeptides 27 195-202.

Straub RE, Frech GC, Joho RH \& Gershengorn MC 1990 Expression cloning of a cDNA encoding the mouse pituitary thyrotropin-releasing hormone receptor. PNAS 87 9514-9518.

Sun Y, Lu X \& Gershengorn MC 2003 Thyrotropin-releasing hormone receptors - similarities and differences. Journal of Molecular Endocrinology 30 87-97.

Voisin L, Foisy S, Giasson E, Lambert C, Moreau P \& Meloche S 2002 EGF receptor transactivation is obligatory for protein synthesis stimulation by $\mathrm{G}$ protein-coupled receptors. American Journal of Physiology 283 C446-C455.

Wolff G, Mastrangeli A, Heinflink M, Falck-Pedersen E, Gershengorn MC \& Crystal RG 1996 Ectopic expression of thyrotropin releasing hormone $(\mathrm{TRH})$ receptors in liver modulates organ function to regulate blood glucose by TRH. Nature Genetics 12 274-279.

Yamada M, Saga Y, Shibusawa N, Hirato J, Murakami M, Iwasaki T, Hashimoto K, Satoh T, Wakabayashi K, Taketo MM \& Mori M 1997 Tertiary hypothyroidism and hyperglycemia in mice with targeted disruption of the thyrotropin-releasing hormone gene. PNAS 94 10862-10867.
Yamada M, Shibusawa N, Hashida T, Ozawa A, Monden T, Satoh T \& Mori M 2000 Expression of thyrotropin-releasing hormone (TRH) receptor subtype 1 in mouse pancreatic islets and HIT-T15, an insulin-secreting clonal $\beta$ cell line. Life Sciences 66 1119-1125.

Yano N, Endoh M, Nomoto Y, Sakai H, Fadden K \& Rifai A 1997 Phenotypic characterization of cytokine expression in patients with IgA nephropathy. Journal of Clinical Immunology 17 396-403.

Yano N, Asakura K, Endoh M, Abe Y, Nomoto Y, Sakai H, Kurokawa K \& Tsukamoto H 1998 Polymorphism in the I 1 germ-line transcript regulatory region and $\operatorname{IgA}$ productivity in patients with IgA nephropathy. Journal of Immunology $\mathbf{1 6 0}$ 4936-4942.

Zabavnik J, Arbuthnott G \& Eidne KA 1993 Distribution of thyrotrophin-releasing hormone receptor messenger RNA in rat pituitary and brain. Neuroscience $\mathbf{5 3} 877-887$.

Received in final form 18 December 2003

Accepted 19 December 2003

Made available online as an

Accepted Preprint 13 February 2004 